\title{
Values Orientation and Marital Conflict Resolution: Implication for Marriage Counselling
}

\author{
Patrick Nyong Asuquo $^{1}$ and Agnes Ebi Maliki ${ }^{2}$ \\ 1. Department of Educational Foundations, Guidance And Counselling, University of Calabar, \\ Calabar, Cross River Sate, 540001, Nigeria \\ E-mail: Patrick.asuquo@shell.com \\ 2. Department of Educational Foundations, Niger Delta University, Wilberforce Island, P.M.B. \\ 071, Bayelsa State, 560001, Nigeria \\ E-mail: agnesmaliki@yahoo.com
}

KEYWORDS Value orientation; marital conflict; resolution; marriage counselling

ABSTRACT The study examined the relationship between values orientation and marital resolution of two hundred married persons using the values orientation and conflict resolution questionnaire (VOCRQ) as well as simple percentage, Pearson product moment and t-test techniques. Result showed that a significant relationship exists between values orientation and conflict resolution. Gender was found to be a significant factor that influences only procreation and security values with regards to conflict resolution. Implications for counselling were discussed.

\section{INTRODUCTION}

The increasing rate of unresolved marital conflict leading to divorce, breakdown of the marriage institution and family life and its psychological effect on the major stakeholders (men, women and children) has in recent years evoked a great deal of concern among counselors all over the world (Mowaiye-Fagbemi and Idowu,1997; Reaman et al., 2001; Wahua, 2001; Morris-Conley and Kern, 2003). Marriage provides the family setting that serves as the nucleus of the society. It creates the home environment which makes for the propagation of species, the rearing of offspring, the emotional reassurance of man's peace of mind, the cultivation of moral values and the balanced interexchange of love as well as security, succor and acceptance. However, when this setting is threatened by turmoil and violence arising from marital conflicts, it has a ripple effect on the society and cumulatively, the world at large. Little wonder that some people perceive the increasing incidence of turmoil, violence, conflict and terrorism that characterize the world scene today as reflecting the state of the family ( Popkin, 2000; Kareen, 2000; Okwoche, 2001). Given the great danger the escalation of conflict at this level portends for the human race, approaches to stemming its tide must be deep-rooted and multidisciplinary so as to bring all relevant knowledge to provide credible solution to the problem. The ever-changing face of the society makes it imperative for issues of conflict not only to occupy the central stage but also to ensure the evolution of workable strategies for resolving present and future conflict so as to forestall its tragic consequences. It must be acknowledged, however, that efforts in this direction will only be effective if related factors like values orientation that predispose marital conflict are understood, isolated and targeted. Counsellors with their incredible base of knowledge and skills in interpersonal relationships are well positioned to make meaningful contribution to this cause.

Marital conflict resolution is said to be a function of a combination of many factors. One of these factors is values orientation (Bernard, 1966; Denga, 1986; Sacco and Phares, 2001). A crucial element, therefore, in a healthy marriage relationship is the congruency between the values system of the wife and that of the husband. Allport as quoted by Asuquo (1992) posits that values exist at some level in the hierarchy of personality and exerts strong influence on learning, aspiration and interests. Evidence that they influence behaviour and perception of variety of objects has been documented by a number of authors (Denga, 1986; Asuquo, 1992; Marshall, 2001). Denga (1986) has emphasized the place of values in a mutually satisfying and harmonious working marital arrangement. Consequently, the absence of it or poor congruency between spouses in 
terms of their values orientation can mean disharmony, dissatisfaction and mutual maladjustment. The result of this values deficit can lead to tension, bitterness, frustration and conflict between marital partners - which may ultimately result in separation or divorce.

In this era of peace and conflict resolution, it is generally believed that the home should be the starting place. The home socializes the child and lays the foundation for future relationship with the wider world. Thus, peaceful home, it is argued produces for its members a cradle for security, happiness and the source of fulfillment of the many human personal needs (Asuquo, 1992). Given this background, managing conflict thus, becomes one of the most important tasks of maintaining a marriage and by implication a peaceful home, and so identifying what factors shape conflict resolution styles is important. This perspective has greatly motivated the conduct of this study. The study is also inspired by the need to orient counselling towards solving the problem of society. As a nation, the present day Nigeria seem to be undergoing a serious value crises, valueslessness, amorality and emptiness going by the alarming degree of corruption and indiscipline among its citizenry. The prevalence of these problems in the larger society has to some extent been attributed to home-related crises arising from unresolved marital conflicts (Uwe, 2000). The different effort to re-orient our value system is clearly indicative of the deep nature of the problem, which calls for assistance to ensure value stabilization in Nigeria. The Nigerian counselor cannot afford to be indifferent to the need to provide assistance with regards to national values clarification, crystallization and stabilization, because to be neutral as far as societal standards concerned would be dangerous. More so, the survival of our nation is partly dependence on helping the individual to acquire a set of values or ethnical system by which to confront and resolve various life conflicts (including marital related) swiftly without resorting to punishing criticism, contempt, defensiveness or spacing out.

Marital breakdown is a product of an unresolved conflict. Shertzer (1973) defined conflict as the "opposition between two impulses or wishes, intended to produce emotional tension and regressed disagreeable impulses. To Denga (1986), it is a clash of personality or interest. Be that as it may, marriage is a setting to expect the manifestation of conflicts. This is because human beings are limited and they are not gods. Therefore, the two individuals who agree or plan to live together as husband and wife in a sacred and permanent relationship are unique and different entities. It is thus, inevitable that individuals involved in such ongoing relationship should experience conflict. Coming from different backgrounds, it is expected that differences exist in their opinions, values, needs, derives and habits. Given this differences no marriage can escape conflict.

The sources of marital conflict are many, varied and interrelated. They include: in-laws, children's discipline, financial instability, personality, barrenness, sexual disharmony, behavioural maladjustment (like alcoholism, smoking, obesity, battering, body ordour, nagging etc) unmet needs, indifference/ insensitivity, infidelity, undue secrecy; Olayinka (1990). It is observed that despite of these conflicts many spouses still cling to each other for various reasons. These reasons have largely been said to relate to or represent conflict resolution abilities anchored on their values orientation. Rogars (1961) posits that an ideal interpersonal relationship is characterized by acceptance, genuiness, positive self-regard and communication of feelings. Ellis (1973) believes that, as a rational being an individual is able to avoid unhappiness by learning to think and resolve issues rationally. Kolo (1992) emphasized the importance of communication.

Values are said to be virtues or convictions that mould and dominate individual action and decision-making. They generally are anything held to be worthwhile, good or desirable by an individual or society. This could be achievement, possessions, characters traits or states of being e.g. happiness. Each one is said to have a hierarchy of them ordered from high to low depending on how important they are to one's life and this hierarchy of values orders the person's behaviour (Wrenn, 1973). That they guide people's decisions and actions as well as give direction to life can be inferred from the words of Shertzer (1973: 146):

Values may be likened to one's conscience or sense of what is right or wrong. A system of values permits a person to endure the pains of a particular situation or to look beyond immediate pleasure. It enables him to impose order on his experiences, so that life is not so confused. Values 
determine the goals define who he is. Values are subjective, that is, every person forms his own ideas of how he should act.

Smith (1962) has identified five specific functions served by values to include:

i. It supplies the individual with a sense of purpose and directions;

ii. It supplies the basis of individual action, and of unified, collective action;

iii. It serves as the basis of judging the behaviour of individuals;

iv. It enables the individual to know what to expect of others as well as how to conduct himself; and

v. It establishes a sense of right and wrong.

It is obvious that values from the foundation of a person's common modes of operation and are so basic in daily interaction. As such they can influence one's decision making, goal setting and actions including conflict resolutions. To that extent, it would not be out of place to assume that they are the central anchor on which the consideration for resolving conflicts arising in marriage revolves. If this is the case, it therefore means that compatibility in the value system between spouses (Denga, 1986) subsumed similarity of personality, attitudes, beliefs and opinions between spouses. The similarity should provide a basis for narrowing the frequency with which conflict occurs in a marriage and a common ground on which those, which occur, are readily resolved without the risk of escalation. Given that ones values system seem to play a central role in ones decisions making and conflict resolution, marriage counselors can benefit immensely from studying the influence of values orientation and conflict resolution. More so, despite the significance and relevant to marital counselling practice, there is little or no research linking these key variables.

The purpose of this study therefore, is to examine the relationship between values orientation and marital conflict resolution. The specific values factors and analyzed are measured on indices of tradition, religion, procreation, success and freedom. The influence of sex on values with regards to conflicts resolutions was also investigated. The findings of the study could provide a basis for marriage counselling with benefit to the individuals and the society. Marriage problems could also be eliminated or minimized if would be wives or husbands receive effective counselling. Further, information generated could form a basis for evaluating various aspects of marriage planning for the overall benefit of individuals in Nigeria. On a broad basis, the study could provide significant data to theory and practice of marriage counselling. By and large, the outcome of the study could be useful to wives, husband, children, employers, government and particularly guidance workers who constitute the primary users of the information.

\section{METHODOLOGY}

A sample of 200 married persons drawn mainly from Calabar Municipality was used for the study. A simple random technique was adopted to ensure effective representation of the married population in the area. They comprised males and females with an average age of 34 years.

The instrument used for the study was developed by the researchers and was subjected to pre-trial using subjects sharing similar characteristics as those in the study. The name of the instrument us values orientation and conflict resolution questionnaire (VOCRQ). It has two sections. Section A was designed to obtain the personal details or demographic data of the subjects. It focused on age, sex, qualification and occupational attainment as well length of marriage (used to select those married 10 years and above) and number of children. Section B comprised 24 Likert type times that assessed the influence of values on participants' conflict resolution. Marital values taxonomies made up of six sub-categories of commonly cherished values among Nigerians earlier developed by Denga (1986) were used. These clusters of values included: Securityoriented, values, religious-oriented values, tradition oriented values, success - oriented values, freedom oriented values and procreation. Responses to the items on the questionnaire ranged from vary important (with 4 points) to vary unimportant (with 1 point). The collected data were analyzed using appropriate statistical tools. With a reliability index of 79 and a construct validity of 70 the instrument was adjudged good enough for the purpose of the study.

\section{RESULTS}

At the end of the analysis, the results were presented in tables 1,2 and 3 to highlight the major findings of the study in line with the research objectives. 
The result above shows the influence of values on conflict resolution. It reveals that $72.5 \%$ of the participant in the study considers certain core values in the resolution of conflicts emanating from their marriages while 27.5 consider values as being unimportant factors in resolving marital conflicts. In specific terms, the results reveals that procreation is the most cherished consideration in resolving marital conflicts $(90 \%)$ followed by religious $(85 \%)$, security $(80 \%)$, success $(65 \%)$, tradition $(60 \%)$ and freedom $(55 \%)$ in that order.

The result as presented above has indicated a high positive correlation values orientation and conflict resolution in all the classificatory variables. These result have therefore shown that majority of the participants consider values as significant factor in their marital conflict resolution efforts.

The values of $t$ obtained in the result above indicate significant differences only on two

Tables 1: Percentage scores of influences of valuesorientation on conflict resolution

\begin{tabular}{llrrrr}
\hline S. & Variables & \multicolumn{4}{c}{ Consideration } \\
\cline { 2 - 6 } & Values orientation cluster & $F$ & $\%$ & $F$ & $\%$ \\
\hline 1 & Security-oriented & 160 & 80 & 40 & 20 \\
2 & Religious-oriented & 170 & 85 & 30 & 25 \\
3 & Tradition-orientation & 120 & 60 & 80 & 40 \\
4 & Success-oriented & 130 & 65 & 70 & 35 \\
5 & Freedom-oriented & 110 & 55 & 90 & 45 \\
6 & Procreation-oriented & 180 & 90 & 20 & 10 \\
& & & 72.5 & & 27.5 \\
\hline
\end{tabular}

Table 2: Correlation coefficients on values orientation and marital conflict resolution $(\mathbf{n = 2 0 0})$

\begin{tabular}{llc}
\hline S. & Values category & $\begin{array}{c}\text { Values orientation/ } \\
\text { conflict resolution } \\
\text { coefficient }\end{array}$ \\
\hline 1 & Security-oriented & .76 \\
2 & Religious-oriented & .70 \\
3 & Tradition-orientation & .50 \\
4 & Success-oriented & .57 \\
5 & Freedom-oriented & .44 \\
6 & Procreation-oriented & .81 \\
\hline
\end{tabular}

classificatory variables of security and procreation (3.10) security (2.50). The t-values for other value categories were not significant (religion, 0.18; tradition, 1.14; success, 0.35; freedom, 1.2). This means, both males and females did not differ statistically in terms of their consideration of these dimensions of their values.

\section{DISCUSSIONAND CONCLUSION}

The findings of the study show that there is a positive relationship between values orientation and marital conflict resolution. The findings agree with previous related findings (Denga, 1986; Kolo, 1993) about the influence of values on behaviour. The probable explanation is that a person's values dominate and mould his actions and decision-making power. In this context, spouses primary values systems have an impact on their capacities for conflict resolution. The specific values involved are traditional, security, religious, success, freedom and procreation - oriented values.

However, when the means the means scores of respondents were compared on the basis of gender, there were no differences between males and females except on security (2.50) and procreation (2.1). Females were found to show more commitment to these values than males going by their means scores. This may be explained from the point of Hughes (1975) who showed that female spouses cherished more values of procreation and security.

The findings of the study have several implications. Counselors should organize awareness education programmes that highlight the place of values in marital conflict resolution frequently. This will provide spouses better frames of mind to appreciate and respect each other's values system.

Counsellors can organize orientation programmes for intended couples and use values -

Table 3: Independent t-test analysis is of sex differences influence of values and marital conflict resolution.

\begin{tabular}{|c|c|c|c|c|c|c|c|c|}
\hline \multirow{2}{*}{$\begin{array}{l}S . \\
\text { No. }\end{array}$} & \multirow[t]{2}{*}{ Variables } & \multicolumn{3}{|c|}{ Male } & \multicolumn{3}{|c|}{ Female } & \multirow[t]{2}{*}{ t-value } \\
\hline & & No. & $X$ & $S D$ & No. & $X$ & $S D$ & \\
\hline 1 & Security-oriented & 106 & 44.6 & 19.96 & 94 & 48.3 & 10.81 & $2.50 *$ \\
\hline 2 & Religious-oriented & 106 & 87.4 & 17.52 & 94 & 87.59 & 6.48 & 0.18 \\
\hline 3 & Tradition-orientation & 106 & 86.90 & 6.48 & 94 & 88.05 & 7.63 & 1.14 \\
\hline 4 & Success-oriented & 106 & 54.68 & 7.98 & 94 & 54.64 & 8.14 & 0.35 \\
\hline 5 & Freedom-oriented & 106 & 47.67 & 12.3 & 94 & 49.48 & 8.03 & 1.2 \\
\hline 6 & $\begin{array}{l}\text { Procreation-oriented } \\
0.05 \text { df } 198: 196\end{array}$ & 106 & 23.61 & 3.57 & 94 & 24.89 & 4.96 & $2.10 *$ \\
\hline
\end{tabular}


clarification techniques to assist individual spouses to be to aware of the impact of values systems on conflict resolution. This because "to be forewarned is to be forearmed".

Furthermore, the counselor can prevail on parents and teachers to focus on development of moral virtues that foster interpersonal relationship among young people. This is to prepare them and enable appropriate values to take root to be made use of when they take their places as husbands and wives in the society.

Finally, counselors can embark o research to generate more information necessary for understanding in more specific terms the interaction of the variables of values - orientation and conflict resolution. Outcome of such research efforts should be disseminated to needy clients.

\section{REFERENCES}

Asuquo, P.N. 1992. Interests, Values and Occupational Aspiration of Youths in Cross Rivers State. Unpublished PhD Thesis, submitted to Graduate School, University of Calabar, Calabar.

Denga, D.I. 1986. "Marital Adjustment and Valuesorientation of selected Nigeria Couples: Implications for Marriage Counselling." The Counsellor, 6(2):1-6

Bernard, J 1966. "Marital Stability and Patterns of Status Variables." Journal of Marriage and Family, 28: 421-439

Ellis, A. 1973. "Rational-emotive Therapy", (Pp. 3244) in R. Corsini (ed.), Current Psychotherapies. Itasca: F.E. Peacock

Hughes, P. M. 1975. Marital Counselling. Oxford: Pergamon Press.

Kareen, J. 2000. Basic Needs, Conflicts and Dynamics in groups. Journal of Individual Psychology, 54(4): 419-434.

Kolo, F.D. 1992. Guidance and Counselling in Perspective. Zaria: Sleveno Printing.

Marshall, E.O. 2001. "The influence of marital satisfaction on the cognitive component of subjective well-being among the elderly." Dissertation Abstract International: Section B: The Sciences and Engineering, 61(7B): 38-50.

Mowaiye-Febgemi, O. and A. I. Idowu.1997. "Physical and Psychosocial effects of Violence on the part of women in Nigeria." The Counsellor, 15(1): 13-20.

Morris-Conley, C.M. and R. M. Kern. 2003. "The Relationship between lifestyle and conflict resolution strategy." Journal of Individual Psychology, 59(4): 475-487.

Okon, S. E. 1983. "Values in Counselling", (Pp. 94 109) in Anslem Uba (ed.), Introduction to Counselling. Ile-Ife: University of Ife Press Ltd.

Okwoche, A.D. 2001."Rising incidence of marital and family conflicts in Nigeria." Edited 25 th Annual CASSON Proceedings Pp.156-160

Olayinka, M. S. 1990. "Job Aspirations of Youths and the Educational Provision in Lagos." West African Journal of Education, 1: 41-49

Popkin, M.H. 2000. "Youth Violence in our Communities: What can we do?" Journal of Individual Psychology, 54(4): 395-410.

Reaman, D.D., J. I. Reaman and J. A. Ako. 2001. "Marriage Conflicts in Counselling." 25 th Annual CASSON Proceedings pp.59-62.

Rogers, C. 1942. Counselling and Psychotherapy. Boston: Houghton Mifflin Company.

Sacco, W.P. and. V. Phares. 2001. "Partner appraisal and Marital Satisfaction: The role of self-esteem and depression." Journal of Marriage and Family, 63(2): 504-513.

Shertzer, B. 1997. Fundamentals of Guidance. Boston: Houghton Miffline Company.

Smith, D. W. 1962. "Value System and the Therapeutic Interview", (Pp. 102-108) in H. J. Peters (ed.), Counselling. Selected Readings. Columbus, Ohio: Charles E. Merril Books.

Uwe, E. A. 2000. "Marital communication", (Pp. 2331) in E. A. Uwe and A. E. Oboit (eds.), Marriage Counselling: Issues and Solutions. Calabar: Pyramid Publishers.

Wahua, T.A.T. 2001. Home Harmony: A Realizable Dream. Port Harcourt: Dalitt Printing and Publishing Company.

Wrenn, C. G. 1973. The Counsellor in a Changing World. Washington: American Personnel and Guidance Association. 